\title{
Data report: cultivation of microorganisms from basaltic rock and sediment cores from the North Pond on the western flank of the Mid-Atlantic Ridge, IODP Expedition $336^{1}$
}

\author{
Hisako Hirayama, ${ }^{2}$ Mariko Abe, ${ }^{2}$ Junichi Miyazaki, ${ }^{2}$ Sanae Sakai, ${ }^{2}$ Yuriko Nagano, ${ }^{3}$ and Ken Takai $^{2}$
}

\section{Chapter contents}

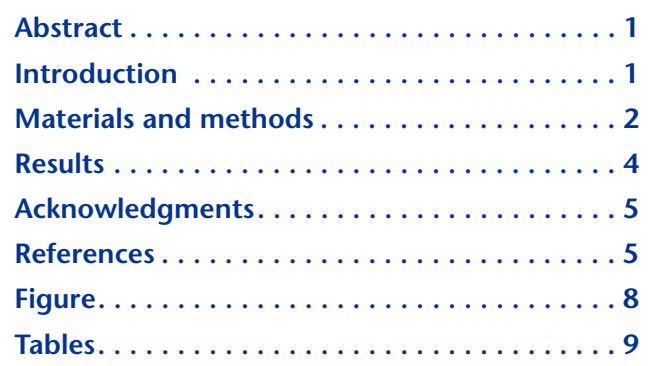

${ }^{1}$ Hirayama, H., Abe, M., Miyazaki, J., Sakai, S., Nagano, Y., and Takai, K., 2015. Data report: cultivation of microorganisms from basaltic rock and sediment cores from the North Pond on the western flank of the Mid-Atlantic Ridge, IODP Expedition 336. In Edwards, K.J., Bach, W., Klaus, A., and the Expedition 336 Scientists, Proc. IODP, 336: Tokyo (Integrated Ocean Drilling Program Management International, Inc.). doi:10.2204/ iodp.proc.336.204.2015

${ }^{2}$ Department of Subsurface Geobiological Analysis and Research, Japan Agency for Marine-Earth Science and Technology (JAMSTEC), 2-15 Natsushima-cho, Yokosuka 237-0061, Japan. Correspondence author:

hirayamah@jamstec.go.jp

${ }^{3}$ Department of Marine Biodiversity Research, Japan Agency for Marine-Earth Science and Technology (JAMSTEC), 2-15 Natsushima-cho, Yokosuka 237-0061, Japan.

\section{Abstract}

Cultivation experiments targeting chemolithoautotrophic microorganisms were performed using subseafloor basaltic cores (the deepest sample is from 315 meters below seafloor [mbsf] and overlying sediment cores (the deepest sample is from $91.4 \mathrm{mbsf}$ ) from North Pond on the western flank of the Mid-Atlantic Ridge. The cores were recovered by the R/V JOIDES Resolution during Integrated Ocean Drilling Program Expedition 336. Different bacteria were grown under different media and temperature conditions. In the enrichment cultures of the basaltic cores under aerobic conditions, frequently detected bacteria at $8^{\circ} \mathrm{C}$ and $25^{\circ} \mathrm{C}$ were members of the genera Ralstonia (the class Betaproteobacteria) and Pseudomonas (Gammaproteobacteria), whereas members of the genera Paenibacillus (Bacilli) and Acidovorax (Betaproteobacteria) were conspicuous at $37^{\circ} \mathrm{C}$. Bacillus spp. (Bacilli) were outstanding at $37^{\circ} \mathrm{C}$ under anaerobic conditions. In the enriched cultures of the sediment cores, bacterial growth was observed at $15^{\circ} \mathrm{C}$ but not at $37^{\circ} \mathrm{C}$, and the bacteria detected at $15^{\circ} \mathrm{C}$ mostly belonged to gammaproteobacterial genera such as Pseudomonas, Halomonas, and Marinobacter. All of the bacteria detected in this study were enriched only, and subcultivation of the enriched cultures in the respective original media did not succeed. The presence of hydrogenotrophic methanogens was examined by a culture-dependent or a culture-independent analysis in the basalt and sediment cores but was not proven. A fungal isolate was obtained from a single basaltic core and belonged to the genus Exophiala of the order Chaetothyriales.

\section{Introduction}

Ocean crust of young age is generally rich in reduced substances such as Fe(II) and sulfur (Bach and Edwards, 2003). Hydrogen was found to be produced from the ocean crust by abiotic basalt-water reactions at low temperature (Stevens and Mckinley, 1995, 2000). These reduced substances in the ocean crust can serve as electron donors for endolithic microorganisms. Meanwhile, seawater is oxic and contains oxygen, nitrate, and sulfate that are preferably utilized as electron acceptors by microorganisms. The circulation of seawater through the upper ocean crust can therefore energize potential endolithic communities in which chemolithoauto- 
trophs utilizing $\mathrm{Fe}(\mathrm{II})$, sulfur, and hydrogen play a role as primary producers. This type of crustal biosphere is most likely to exist on young ridge flanks (Fisher et al., 2003; Lever et al., 2013; McCarthy et al., 2011). The North Pond site located on the western flank of the Mid-Atlantic Ridge is one of ideal study sites to examine the ridge flank crustal biosphere (see the "Expedition 336 summary" chapter [Expedition 336 Scientists, 2012a]).

The results of several cultivation studies targeting endolithic or crustal fluid microorganisms have been reported previously. The results from experiments using basaltic core samples collected during Ocean Drilling Program (ODP) Leg 187 at Southeast Indian Ridge (maximum penetration was 374 meters below seafloor [mbsf]) presented the methane production and $\mathrm{Fe}(\mathrm{III})$ reduction in enrichment cultures, indicating the existence of active hydrogenotrophic methanogens and Fe(III)-reducing microorganisms within the cores (Lysnes et al., 2004). Cultivation of seafloor basalts collected at low- and high-temperature fluid vent systems along the Mid-Atlantic Ridge detected diverse bacteria belonging to the classes Alphaproteobacteria, Betaproteobacteria, Gammaproteobacteria, Actinobacteria, and Bacilli, and some of the isolates that were assigned to the genus Bacillus were shown to grow on a medium specific for manganese oxidizers (Rathsack et al., 2009). In a study of an Integrated Ocean Drilling Program (IODP) site on the Juan de Fuca Ridge flank, in situ colonization systems deployed in the borehole for 4 years revealed the presence of active and cultivable Fe(II)-oxidizing bacteria belonging to eight genera, including gammaproteobacterial Alcanivorax, Marinobacter, and $\mathrm{Ha}$ lomonas as the predominant genera; however, all cultivated bacteria that utilized low-organic compounds for their growth were not proven to be facultative chemolithoautotrophs in that study (Smith et al., 2011). The existence of methanogens and sulfate reducers in the subseafloor basalt was indicated by a combination of molecular phylogenetic, isotopic, and cultivation analyses using cores collected at the Juan de Fuca Ridge flank during IODP Expedition 301 (Lever et al., 2013). Ocean crust is also inferred to provide habitats for fungi; it has been used to examine fossilized fungi-like filamentous or spherical structures found in thin sections of basaltic cores collected during ODP legs (Ivarsson et al., 2012; Schumann et al., 2004).

Although many microorganisms have been previously enriched or isolated from ocean crust as mentioned above, most of those seem to be heterotrophs. We therefore tried to cultivate chemolithoautotrophic microorganisms from cores of basalt and overlying sediments retrieved by the R/V JOIDES Res- olution from a North Pond site during IODP Expedition 336.

\section{Materials and methods}

\section{Subsampling of cores}

Pieces of rock cores collected for microbiology were subsampled for several analyses (see the "Methods" chapter [Expedition 336 Scientists, 2012b]), and a portion was used for this study. Each piece of rock (10-20 $\mathrm{cm}^{3}$ per piece) was immediately transferred into the anaerobic chamber settled in the onboard cold room after the subsampling and then smashed using a tungsten carbide cylinder mortar. The smashed rock was put into a $100 \mathrm{~mL}$ glass bottle and sealed tightly with a butyl rubber cap in the anaerobic chamber. The bottles were kept cool before starting shore-based cultivations.

A $10 \mathrm{~cm}$ whole-round sediment sample was cut from a sediment core on the catwalk for this study (see the "Methods" chapter [Expedition 336 Scientists, $2012 \mathrm{~b}]$ ) and kept at $4^{\circ} \mathrm{C}$ before further processing. The following process was promptly conducted on the onboard laboratory bench to minimize laboratory contamination and exposure to oxygen. The surface of the whole-round sample was trimmed with a stainless steel spatula, and $10 \mathrm{~cm}^{3}$ of the sediment was taken from the center with a cut syringe. The syringe sample was put into a $100 \mathrm{~mL}$ glass bottle, and the headspace was purged with nitrogen gas. The bottle was sealed tightly with a butyl rubber cap. The bottles were kept at $4^{\circ} \mathrm{C}$ before starting shore-based cultivations. Another portion of the sediment sample was taken for DNA analysis; a syringe sample $\left(7-10 \mathrm{~cm}^{3}\right)$ was put in a plastic tube, and frozen at $-20^{\circ} \mathrm{C}$ and kept frozen before the shore-based analysis.

\section{Preparation of growth media}

Cultivation media used in this study are summarized in Table T1. For hydrogenotrophic methanogens, 20 $\mathrm{mL}$ of marine medium salts in artificial seawater (MMJ) medium was prepared in a $70 \mathrm{~mL}$ glass vial as previously reported (Takai et al., 2002). For other microorganisms, respective cultivation media were prepared using the basic seawater medium. The basic seawater medium was prepared by adding $0.06 \mathrm{~g}$ $\mathrm{KH}_{2} \mathrm{PO}_{4}, 0.17 \mathrm{~g} \mathrm{Na}_{2} \mathrm{HPO}_{4}$, and $0.25 \mathrm{~g} \mathrm{NH}_{4} \mathrm{NO}_{3}$ in $1 \mathrm{~L}$ of commercial artificial seawater MARINE ART SF-1 (Osaka Yakken), which did not contain any organic compound. A $3 \mathrm{~mL}$ portion of each growth medium was prepared in a $15 \mathrm{~mL}$ test tube with a butyl rubber cap. Headspace was replaced with each gas composition shown in Table T1. 


\section{Enrichment cultures}

Slurry was prepared using each core sample in an onshore laboratory after the expedition. The smashed rock sample was suspended with $20-40 \mathrm{~mL}$ of the anaerobic artificial seawater, which was injected in a glass bottle by a syringe. The sediment sample was suspended with $20 \mathrm{~mL}$ of the anaerobic artificial seawater. The total 33 rock cores and 30 sediment cores were subjected to enrichments. A $0.3 \mathrm{~mL}$ portion of slurry was inoculated into each medium, and enrichments were performed for 4-8 months at temperatures shown in Tables T2, T3, and T4.

\section{Bacterial and archaeal rRNA gene analyses}

Some microbial cells in the enrichment cultures were distinguished from rock or sediment particles by microscopy; however, exact cell counting of the enrichment cultures was difficult because of deceptive celllike particles in the cultures. Genomic DNA was then extracted from $1 \mathrm{~mL}$ of every culture using ISOIL for Beads Beating (NIPPON GENE) according to the manufacturer's instructions. The volume of the final DNA extract was $15 \mu \mathrm{L}$. Bacterial and archaeal $16 \mathrm{~S}$ rRNA genes were amplified from the extracted DNA by polymerase chain reaction (PCR) in each $15 \mu \mathrm{L}$ volume of reaction mixture containing the following:

- 1xGC buffer I (Takara Bio),

- $0.33 \mathrm{mM}$ each dNTP (deoxynucleotide),

- $0.33 \mu \mathrm{M}$ each primer,

- $1.25 \mathrm{U}$ (units) of LA Taq polymerase (TaKaRa Bio), and

- $3.7 \mu \mathrm{L}$ of genomic DNA extract.

Primers were Bac27F and Uni1492R for bacteria and Arc21F and Uni1492R for archaea (DeLong, 1992; Lane, 1991). The amplification was performed using Veriti Thermal Cycler (Applied Biosystems) with the following program:

1. $96^{\circ} \mathrm{C}$ for $1 \mathrm{~min}$,

2. 37 cycles of $96^{\circ} \mathrm{C}$ for $25 \mathrm{~s}$,

3. $50^{\circ} \mathrm{C}$ (archaea) or $53^{\circ} \mathrm{C}$ (bacteria) for $45 \mathrm{~s}$,

4. $72^{\circ} \mathrm{C}$ for $90 \mathrm{~s}$, and

5. $72^{\circ} \mathrm{C}$ for $10 \mathrm{~min}$.

In the PCR amplification, a negative control containing no DNA extract was always examined to exclude contamination. In addition, contamination in the DNA extraction kit was sometimes examined by doing the extraction procedure without a sample and the following PCR amplification.

Aliquots of $2 \mu \mathrm{L}$ of PCR products were analyzed by agarose gel electrophoresis and ethidium bromide staining. The amplified 16S rRNA gene fragments shown as clearly visible bands were sequenced by di- rect sequencing or after cloned into vector pCR2.1 with TA Cloning Kit (Invitrogen). Partial 16S rRNA gene sequences were analyzed by $3130 \times 1$ Genetic Analyzer (Applied Biosystems). The obtained sequences were compared against the DNA database using BLAST (blast.st-va.ncbi.nlm.nih.gov/Blast.cgi).

\section{Analysis of a fungal isolate}

A fungal isolate was routinely cultivated on an agar plate prepared with $2 \mathrm{~g}$ yeast extract, $2 \mathrm{~g}$ peptone, $2 \mathrm{~g}$ maltose, and $15 \mathrm{~g}$ agar per $1 \mathrm{~L}$ of artificial seawater MARINE ART SF-1. DNA was extracted and analyzed as described above for bacterial and archaeal DNA analyses. DNA fragments including 18S, 5.8S, and $28 \mathrm{~S}$ rRNA coding regions and the internal transcribed spacer (ITS) regions were obtained by PCR. PCR amplification was first conducted using the following three sets of primers (biology.duke.edu/ fungi/mycolab/primers.htm):

- EU347F and EUK-B (Medlin et al., 1988; Puitika et al., 2007),

- ITS1 and ITS4 (White et al., 1990), and

- LTOR and LR5.

After sequencing the PCR products, blank regions were determined by primer walking to extend the sequences. The obtained sequence was compared against the DNA database using BLAST and analyzed to construct a phylogenetic tree as described previously (Hirayama et al., 2013).

\section{Measurement of methane production}

Methane production in rock core enrichment cultures targeting methanogens was examined by injecting $0.1 \mathrm{~mL}$ of headspace gas from each vial into a gas chromatograph GC-3200 (GL Science) equipped with a thermal conductivity detector and a SHINCARBON ST 50/80 column (Shinwa Chemical Industries). The detection limit was approximately $10 \mu \mathrm{M}$.

\section{Real-time PCR of the methyl coenzyme-M reductase subunit $A$ gene ( $m c r A)$}

Genomic DNA was extracted from $1 \mathrm{~g}$ of frozen sediment using ISOIL for Beads Beating. A $2 \mu \mathrm{L}$ portion of the total $20 \mu \mathrm{L}$ DNA extract was used for a realtime PCR experiment to examine the presence of methanogens in the sediment cores by amplification of the methyl coenzyme- $M$ reductase subunit $A$ gene $m c r A$, which is the key enzyme gene of methanogens. SYBR green dye-based PCR amplification and detection were performed using SYBR Premix Ex Taq (TaKaRa Bio) and a 7500 Real-Time PCR system (Applied Biosystems) as described previously (Nunoura et al., 2008). 


\section{Results}

In a negative control for PCR experiment, a reaction mixture added with pure water instead of DNA extract sometimes generated a slightly visible PCR band of $16 \mathrm{~S}$ rRNA gene fragments. The retrieved sequences always indicated $99 \%$ identity to that of Nesterenkonia aethiopica in the class Actinobacteria. We considered enrichment cultures from which sequences similar to the negative control sequence were detected as growth-negative.

\section{Anaerobic enrichments from rock cores}

Cultivations targeting anaerobic hydrogenotrophic methanogens were performed at three different temperatures of $15^{\circ} \mathrm{C}, 37^{\circ} \mathrm{C}$, and $55^{\circ} \mathrm{C}$, and each headspace gas was examined by gas chromatography analysis; however, methane production was not detected from any of the enrichment cultures. The other targeted anaerobic metabolism was hydrogen oxidation. The medium containing hydrogen as an electron donor and sulfate and nitrate as electron acceptors was used for enrichments. Apparent microbial growth was not detected in any of the enrichment cultures at $15^{\circ} \mathrm{C}$, whereas the enrichment cultures at $37^{\circ} \mathrm{C}$ showed bacterial growth from nine core samples (Table T2). The detected bacteria were affiliated to the genera Bacillus, Methylobacterium, and Sphingomonas by direct sequencing analysis of $16 \mathrm{~S}$ rRNA genes. Bacillus spp. have previously been cultivated from subsurface basaltic cores and the inside of seafloor basaltic rocks (Lysnes et al., 2004; Rathsack et al., 2009). Although two Bacillus spp., Bacillus schlegelii and Bacillus tusciae, were previously known to be facultatively chemolithoautotrophic hydrogen-oxidizing bacteria, these species have recently been reclassified in novel genera Hydrogenibacillus (Kämpfer et al., 2013) and Kyrpidia (Klenk et al., 2011), respectively. To our knowledge, no other $\mathrm{Ba}$ cillus spp. are reported to be capable of hydrogen oxidation.

The archaeal 16S rRNA gene was not amplified from any of the anaerobic cultures.

\section{Aerobic enrichments from rock cores}

For aerobic cultivations, reduced sulfur compounds (elemental sulfur and thiosulfate) and hydrogen were used as electron donors. Two enrichment cultures targeting sulfur oxidizers indicated bacterial growth, and Moraxella sp. was detected from one of the two examined cultures. Enrichments targeting hydrogen oxidizers were more prolific than those targeting sulfur oxidizers. Bacterial growth was de- tected from 10, 8, and 13 core samples cultivated at $8^{\circ} \mathrm{C}, 25^{\circ} \mathrm{C}$, and $37^{\circ} \mathrm{C}$, respectively (Table $\mathrm{T} 3$ ).

Members of the genera Ralstonia and Pseudomonas were most frequently detected in the enrichment cultures at $8^{\circ} \mathrm{C}$ and $25^{\circ} \mathrm{C}$. Ralstonia and Pseudomonas spp. have previously been detected in cultivation analyses of the subsurface and seafloor basaltic rocks and also in culture-independent microbial community analyses of deep subsurface gabbroic rock cores (Lysnes et al., 2004; Mason et al., 2010; Rathsack et al., 2009). Ralstonia spp. are known to be tough microorganisms (Mijnendonckx et al., 2013), and they might be living in various harsh environments, including nutrient-starved endolithic habitats. In the genus Ralstonia, only one species, Ralstonia eutropha, was previously known to be a facultatively chemolithoautotrophic hydrogen-oxidizing bacterium; however, $R$. eutropha was reclassified in the genus Cupriavidus later and now is recognized as a synonym of Cupriavidus necator (Vandamme and Coenye, 2004). Currently, it seems that there is no published data about chemolithotrophic hydrogenoxidizing species of the genera Ralstonia and Pseudomonas.

A PCR amplification of the culture of the sample from Section 336-U1382A-6R-1A at $8^{\circ} \mathrm{C}$ generated a dense product band, but direct sequencing of the product did not succeed. The product was then cloned, and 16S rRNA gene sequences similar to those of Salinibacterium and Sphingomonas spp. were obtained. Salinibacterium amurskyense is a marine heterotroph capable of growing at $4^{\circ} \mathrm{C}$ (Han et al., 2003). The genus Sphingomonas is known for the ability to degrade a wide range of recalcitrant environmental pollutants (Yabuuchi and Kosako, 2005). In the enrichment culture of Section 336-U1383C$24 \mathrm{R}-1 \mathrm{~A}$ at $25^{\circ} \mathrm{C}$, visible growth of black fungi-like cells was observed, and then the culture was analyzed separately as described below.

In the enrichment cultures at $37^{\circ} \mathrm{C}$, Paenibacillus and Acidovorax spp. were frequently detected. A Paenibacillus species has previously been cultivated from subsurface basaltic cores (Lysnes et al., 2004). Several Paenibacillus spp. have been associated with Fe(III) reduction and have been reported to predominate in the $\mathrm{Fe}(\mathrm{III})$-reducing consortia of subsurface sediments in terrestrial heavy metal-contaminated sites (Ahmed et al., 2012; Petrie et al., 2003). Although the genus Acidovorax is generally characterized by chemoorganotrophic growth, Acidovorax ebreus has reported as a mixotroph to utilize $\mathrm{Fe}(\mathrm{II})$ as the electron donor (Byrne-Bailey et al., 2010). The lithoautotrophic growth by hydrogen oxidation has also been 
reported in strains of two species of the genus Acidovorax, Acidovorax facilis and Acidovorax delafieldii (Willems et al., 1990).

The archaeal 16S rRNA gene was not amplified from any of the aerobic cultures.

\section{Detection of the mcrA gene of methanogens from sediment cores}

To select sediment cores suitable for the cultivation of methanogens, amplification of the mcrA genes in DNA from sediment cores was attempted using realtime PCR. The mcrA gene was, however, not detected in any of the sediment cores (Table T2). Therefore, cultivation of methanogens was not performed on the sediment cores.

\section{Enrichments from sediment cores}

Sediment core samples were used for inoculation of aerobic enrichments in the medium for sulfur oxidizers at temperatures of $15^{\circ} \mathrm{C}$ and $37^{\circ} \mathrm{C}$. Bacterial growth was observed in seven core samples at $15^{\circ} \mathrm{C}$, whereas there was no clear indication of microbial growth in the enrichment cultures at $37^{\circ} \mathrm{C}$ (Table T4). The bacteria detected in the cultures at $15^{\circ} \mathrm{C}$ were members of the genera Pseudomonas, Halomonas, Marinobacter, and Paracoccus. Members of these genera are known to be typical inhabitants of subsurface sediments (Parkes et al., 2014). It has been reported that strains belonging to these genera are obligately heterotrophic sulfur oxidizers, which means they can utilize sulfur compounds as electron donors and organic compounds as carbon sources, or facultatively autotrophic sulfur oxidizers (Petri et al., 2001; Sorokin, 2003; Van Spanning, 2005). In thiosulfate-oxidizing heterotrophic Pseudomonas stutzeri, the presence of thiosulfate dehydrogenase participating in thiosulfate oxidation and the exhibition of it's enzymatic activity were proven by using an expressed recombinant protein (Denkmann et al., 2012).

The archaeal 16S rRNA gene was not amplified from any of the aerobic cultures.

\section{A fungal isolate from the rock core}

Fungal growth was observed in the enriched culture from Core $336-\mathrm{U} 1383 \mathrm{C}-24 \mathrm{R}-1 \mathrm{~A}$ rock at $25^{\circ} \mathrm{C}$ as described above. The isolated fungal strain was designated NPf1. A sequence of $\sim 4.4 \mathrm{kbp}$ including $18 \mathrm{~S}$, $5.8 \mathrm{~S}$, and $28 \mathrm{~S}$ rRNA coding regions and the internal transcribed spacer regions (ITS1 and ITS2) was obtained from the isolate (GenBank/EMBL/DDBJ accession number LC017736). The isolate NPf1 was affiliated to the genus Exophiala of the order Chaetothyriales by similarity analysis (Fig. F1). It has been reported that many fungal isolates from terrestrial rocks are grouped into the order Chaetothyriales (Sterflinger et al., 1997; Ruibal et al., 2008).

We succeeded in retrieving partial 16S rRNA gene sequences by the direct sequencing of PCR products from most of the growth-positive enrichment cultures, suggesting that the detected microorganisms were certainly grown in the enrichment cultures. However, we did not achieve the subcultivation of the detected bacteria in the respective original media in any case. Because the enrichment cultures contained rock particles as inocula transferred from the slurry, rock minerals might be needed for their growth.

\section{Acknowledgments}

This research used samples provided by the Integrated Ocean Drilling Program (IODP). We thank the captain, crew, and technicians of the R/V JOIDES Resolution, Co-Chief scientists Katrina J. Edwards and Wolfgang Bach, and the IODP Expedition 336 shipboard scientific party, especially the members of the microbiology team. We also thank Kentaro Nakamura for helpful discussion and Takuro Nunoura and Miho Hirai for their assistance in the $\mathrm{mcr} A$ detection procedure.

\section{References}

Ahmed, B., Cao, B., McLean, J.S., Ica, T., Dohnalkova, A., Istanbullu, O., Paksoy, A., Fredrickson, J.K., and Beyenal, H., 2012. Fe(III) reduction and U(VI) immobilization by Paenibacillus sp. strain 300A, isolated from Hanford 300A subsurface sediments. Appl. Environ. Microbiol., 78(22):8001-8009. doi:10.1128/AEM.01844-12

Bach, W., and Edwards, K.J., 2003. Iron and sulfide oxidation within the basaltic ocean crust: implications for chemolithoautotrophic microbial biomass production. Geochim. Cosmochim. Acta, 67(20):3871-3887. doi:10.1016/S0016-7037(03)00304-1

Byrne-Bailey, K.G., Weber, K.A., Chair, A.H., Bose, S., Knox, T., Spanbauer, T.L., Chertkov, O., and Coates, J.D., 2010. Completed genome sequence of the anaerobic iron-oxidizing bacterium Acidovorax ebreus strain TPSY. J. Bacteriol., 192(5):1475-1476. doi:10.1128/JB.01449-09

DeLong, E.F., 1992. Archaea in coastal marine environments. Proc. Natl. Acad. Sci. U. S. A., 89(12):5685-5689. doi:10.1073/pnas.89.12.5685

Denkmann, K., Grein, F., Zigann, R., Siemen, A., Bergmann, J., van Helmont, S., Nicolai, A., Pereira, I.A.C., and Dahl, C., 2012. Thiosulfate dehydrogenase: a widespread unusual acidophilic c-type cytochrome. Environ. Microbiol., 14(10):2673-2688. doi:10.1111/j.14622920.2012.02820.x

Expedition 336 Scientists, 2012a. Expedition 336 summary. In Edwards, K.J., Bach, W., Klaus, A., and the 
Expedition 336 Scientists, Proc. IODP, 336: Tokyo (Integrated Ocean Drilling Program Management International, Inc.). doi:10.2204/iodp.proc.336.101.2012

Expedition 336 Scientists, 2012b. Methods. In Edwards, K.J., Bach, W., Klaus, A., and the Expedition 336 Scientists, Proc. IODP, 336: Tokyo (Integrated Ocean Drilling Program Management International, Inc.). doi:10.2204/iodp.proc.336.102.2012

Fisher, A.T., Davis, E.E., Hutnak, M., Spiess, V., Zühlsdorff, L., Cherkaoui, A., Christiansen, L., Edwards, K., Macdonald, R., Villinger, H., Mottl, M.J., Wheat, C.G., and Becker, K., 2003. Hydrothermal recharge and discharge across $50 \mathrm{~km}$ guided by seamounts on a young ridge flank. Nature, 421(6923):618-621. doi:10.1038/ nature01352

Han, S.K., Nedashkovskaya, O.I., Mikhailov, V.V., Kim, S.B., and Bae, K.S., 2003. Salinibacterium amurskyense gen. nov., sp. nov., a novel genus of the family Microbacteriaceae from the marine environment. Int. J. Syst. Evol. Microbiol., 53(6):2061-2066. doi:10.1099/ijs.0.02627-0

Hirayama, H., Fuse, H., Abe, M., Miyazaki, M., Nakamura, T., Nunoura, T., Furushima, Y., Yamamoto, H., and Takai, K., 2013. Methylomarinum vadi gen. nov., sp. nov., a methanotroph isolated from two distinct marine environments. Int. J. Syst. Evol. Microbiol., 63(3):1073-1082. doi:10.1099/ijs.0.040568-0

Ivarsson, M., Bengtson, S., Belivanova, V., Stampanoni, M., Marone, F., and Tehler, A., 2012. Fossilized fungi in subseafloor Eocene basalts. Geology, 40(2):163-166. doi:10.1130/G32590.1

Kämpfer, P., Glaeser, S.P., and Busse, H.-J., 2013. Transfer of Bacillus schlegelii to a novel genus and proposal of Hydrogenibacillus schlegelii gen. nov., comb. nov. Int. J. Syst. Evol. Microbiol., 63(5):1723-1727. doi:10.1099/ ijs.0.045146-0

Klenk, H.-P., Lapidus, A., Chertkov, O., Copeland, A., Del Rio, T.G., Nolan, M., Lucas, S., Chen, F., Tice, H., Cheng, J.-F., Han, C., Bruce, D., Goodwin, L., Pitluck, S., Pati, A., Ivanova, N., Mavromatis, K., Daum, C., Chen, A., Palaniappan, K., Chang, Y., Land, M., Hauser, L., Jeffries, C.D., Detter, J.C., Rohde, M., Abt, B., Pukall, R., Göker, M., Bristow, J., Markowitz, V., Hugenholtz, P., and Eisen, J.A., 2011. Complete genome sequence of the thermophilic, hydrogen-oxidizing Bacillus tusciae type strain (T2) and reclassification in the new genus, Kyrpidia gen. nov. as Kyrpidia tusciae comb. nov. and emendation of the family Alicyclobacillaceae da Costa and Rainey, 2010. Stand. Genomic. Sci., 5(1):121-134. doi:10.4056/ sigs. 2144922

Lane, D.J., 1991. 16S/23S rRNA sequencing. In Stackebrandt, E., and Goodfellow, M. (Eds.), Nucleic Acid Techniques in Bacterial Systematics: New York (Wiley), 115148.

Lever, M.A., Rouxel, O., Alt, J.C., Shimizu, N., Ono, S., Coggon, R.M., Shanks, W.C., III, Laphan, L., Elvert, M., Prieto-Mollar, X., Hinrichs, K.-U., Inagaki, F., and Teske, A., 2013. Evidence for microbial carbon and sulfur cycling in deeply buried ridge flank basalt. Science, 339(6125):1305-1308. doi:10.1126/science.1229240
Lysnes, K., Torsvik, T., Thorseth, I.H., and Pedersen, R.B., 2004. Microbial populations in ocean floor basalt: results from ODP Leg 187. In Pedersen, R.B., Christie, D.M., Miller, D.J. (Eds.), Proc. ODP, Sci. Results, 187: College Station, TX (Ocean Drilling Program), 1-27. doi:10.2973/odp.proc.sr.187.203.2004

Mason, O.U., Nakagawa, T., Rosner, M., Van Nostrand, J.D., Zhou, J., Maruyama, A., Fisk, M.R., and Giovannoni, S.J., 2010. First investigation of the microbiology of the deepest layer of ocean crust. PLoS One, 5(11):e15399. doi:10.1371/journal.pone.0015399

McCarthy, M.D., Beaupré, S.R., Walker, B.D., Voparil, I., Guilderson, T.P., and Druffel, E.R.M., 2011. Chemosynthetic origin of ${ }^{14} \mathrm{C}$-depleted dissolved organic matter in a ridge-flank hydrothermal system. Nat. Geosci., 4(1):32-36. doi:10.1038/ngeo1015

Medlin, L., Elwood, H.J., Stickel, S., and Sogin, M.L., 1988. The characterization of enzymatically amplified eukaryotic 16S-like rRNA-coding regions. Gene, 71(2):491-499. doi:10.1016/0378-1119(88)90066-2

Mijnendonckx, K., Provoost, A., Ott, C.M., Venkateswaran, K., Mahillon, J., Leys, N., and Van Houdt, R., 2013. Characterization of the survival ability of Cupriavidus metallidurans and Ralstonia pickettii from space-related environments. Microb. Ecol., 65(2):347-360. doi:10.1007/s00248-012-0139-2

Nunoura, T., Oida, H., Miyazaki, J., Miyashita, A., Imachi, H., and Takai, K., 2008. Quantification of $m c r A$ by fluorescent PCR in methanogenic and methanotrophic microbial communities. FEMS Microbiol. Ecol., 64(2):240-247. doi:10.1111/j.1574-6941.2008.00451.x

Parkes, R.J., Cragg, B., Roussel, E., Webster, G., Weightman, A., and Sass, H., 2014. A review of prokaryotic populations and processes in sub-seafloor sediments, including biosphere:geosphere interactions. Mar. Geol., 352:409425. doi:10.1016/j.margeo.2014.02.009

Petri, R., Podgorsek, L., and Imhoff, J.F., 2001. Phylogeny and distribution of the soxB gene among thiosulfateoxidizing bacteria. FEMS Microbiol. Lett., 197(2):171178. doi:10.1016/S0378-1097(01)00111-2

Petrie, L., North, N.N., Dollhopf, S.L., Balkwill, D.L., and Kostka, J.E., 2003. Enumeration and characterization of iron(III)-reducing microbial communities from acidic subsurface sediments contaminated with uranium(VI). Appl. Environ. Microbiol., 69(12):7467-7479. doi:10.1128/AEM.69.12.7467-7479.2003

Puitika, T., Kasahara, Y., Miyoshi, N., Sato, Y., and Shimano, S., 2007. A taxon-specific oligonucleotide primer set for PCR-based detection of soil ciliate. Microbes Environ., 22(1):78-81. doi:10.1264/jsme2.22.78

Rathsack, K., Stackebrandt, E., Reitner, J., and Schumann, G., 2009. Microorganisms isolated from deep sea lowtemperature influenced oceanic crust basalts and sediment samples collected along the Mid-Atlantic Ridge. Geomicrobiol. J., 26(4):264-274. doi:10.1080/ 01490450902892456

Ruibal, C., Platas, G., and Bills, G.F., 2008. High diversity and morphological convergence among melanised 
fungi from rock formations in the Central Mountain System of Spain. Persoonia, 21:93-110. doi:10.3767/ 003158508X371379

Schumann, G., Manz, W., Reitner, J., and Lustrino, M., 2004. Ancient fungal life in north Pacific Eocene oceanic crust. Geomicrobiol. J., 21(4):241-246. doi:10.1080/ 01490450490438748

Smith, A., Popa, R., Fisk, M., Nielsen, M., Wheat, C.G., Jannasch, H.W., Fisher, A.T., Becker, K., Sievert, S.M., and Flores, G., 2011. In situ enrichment of ocean crust microbes on igneous minerals and glasses using an osmotic flow-through device. Geochem., Geophys., Geosyst., 12(6):Q06007. doi:10.1029/2010GC003424

Sorokin, D.Y., 2003. Oxidation of inorganic sulfur compounds by obligately organotrophic bacteria. Microbiology, 72(6):641-653. doi:10.1023/

B:MICI.0000008363.24128.e5

Sterflinger, K., De Baere, R., de Hoog, G.S., De Wachter, R., Krumbein, W.E., and Haase, G., 1997. Coniosporium perforans and C. apollinis, two new rock-inhabiting fungi isolated from marble in the Sanctuary of Delos (Cyclades, Greece). Antonie Van Leeuwenhoek, 72(4):349363. doi:10.1023/A:1000570429688

Stevens, T.O., and McKinley, J.P., 1995. Lithoautotrophic microbial ecosystems in deep basalt aquifers. Science, 270(5235):450-454. doi:10.1126/science.270.5235.450

Stevens, T.O., and McKinley, J.P., 2000. Abiotic controls on $\mathrm{H}_{2}$ production from basalt-water reactions and implications for aquifer biogeochemistry. Environ. Sci. Technol., 34(5):826-831. doi:10.1021/es990583g

Takai, K., Inoue, A., and Horikoshi, K., 2002. Methanothermococcus okinawensis sp. nov., a thermophilic, methaneproducing archaeon isolated from a Western Pacific deep-sea hydrothermal vent system. Int. J. Syst. Evol. Microbiol., 52(4):1089-1095. doi:10.1099/ijs.0.02106-0
Van Spanning, R.J.M., Stouthamer, A.H., Baker, S.C., and van Verseveld, H.W., 2005. Class I. Alphaproteobacteria, Order III. Rhodobacterales, Family 1. Rhodobacteraceae, Genus XII. Paracoccus. In Garrity, G.M., Brenner, D.J., Krieg, N.R., and Staley, J.T. (Eds.), Bergey's Manual of Systematic Bacteriology (Vol. 2): The Proteobacteria (Part C): New York (Springer), 197-204.

Vandamme, P., and Coenye, T., 2004. Taxonomy of the genus Cupriavidus: a tale of lost and found. Int. J. Syst. Evol. Microbiol., 54(6):2285-2289. doi:10.1099/ ijs.0.63247-0

White, T.J., Bruns, T., Lee, S., and Taylor, J.W., 1990. Amplification and direct sequencing of fungal ribosomal RNA genes for phylogenetics. In Innis, M.A., Gelfand, D.H., Sninsky, J.J., and White, T.J. (Eds.), PCR Protocols: A Guide to Methods and Applications: London (Academic Press), 315-322. doi:10.1016/B978-0-12-3721808.50042-1

Willems, A., Falsen, E., Pot, B., Jantzen, E., Hoste, B., Vandamme, P., Gillis, M., Kersters, K., and De Ley, J., 1990. Acidovorax, a new genus for Pseudomonas facilis, Pseudomonas delafieldii, E. Falsen (EF) group 13, EF group 16, and several clinical isolates, with the species Acidovorax facilis comb. nov., Acidovorax delafieldii comb. nov., and Acidovorax temperans sp. nov. Int. J. Syst. Bacteriol., 40(4):384-398. doi:10.1099/00207713-40-4-384

Yabuuchi, E., and Kosako, Y., 2005. Class I. Alphaproteobacteria, Order IV. Sphingomonadales, Family I. Sphingomonadaceae, Genus I. Sphingomonas. In Garrity, G.M., Brenner, D.J., Krieg, N.R., and Staley, J.T. (Eds.), Bergey's Manual of Systematic Bacteriology (Vol. 2): The Proteobacteria (Part C): New York (Springer), 234-258.

Initial receipt: 5 September 2014

Acceptance: 25 February 2015

Publication: 28 April 2015

MS 336-204 
Figure F1. Neighbor-joining phylogenetic tree based on partial 28S rRNA gene sequences (464 bp) showing the position of the isolate NPf1 among representative species of the order Chaetothyriales. Bootstrap analyses were performed (100 replicates), and only bootstrap values $>50 \%$ are shown. Solid dots $=$ spp. which are reported to be isolated from terrestrial rocks (Ruibal et al., 2008).

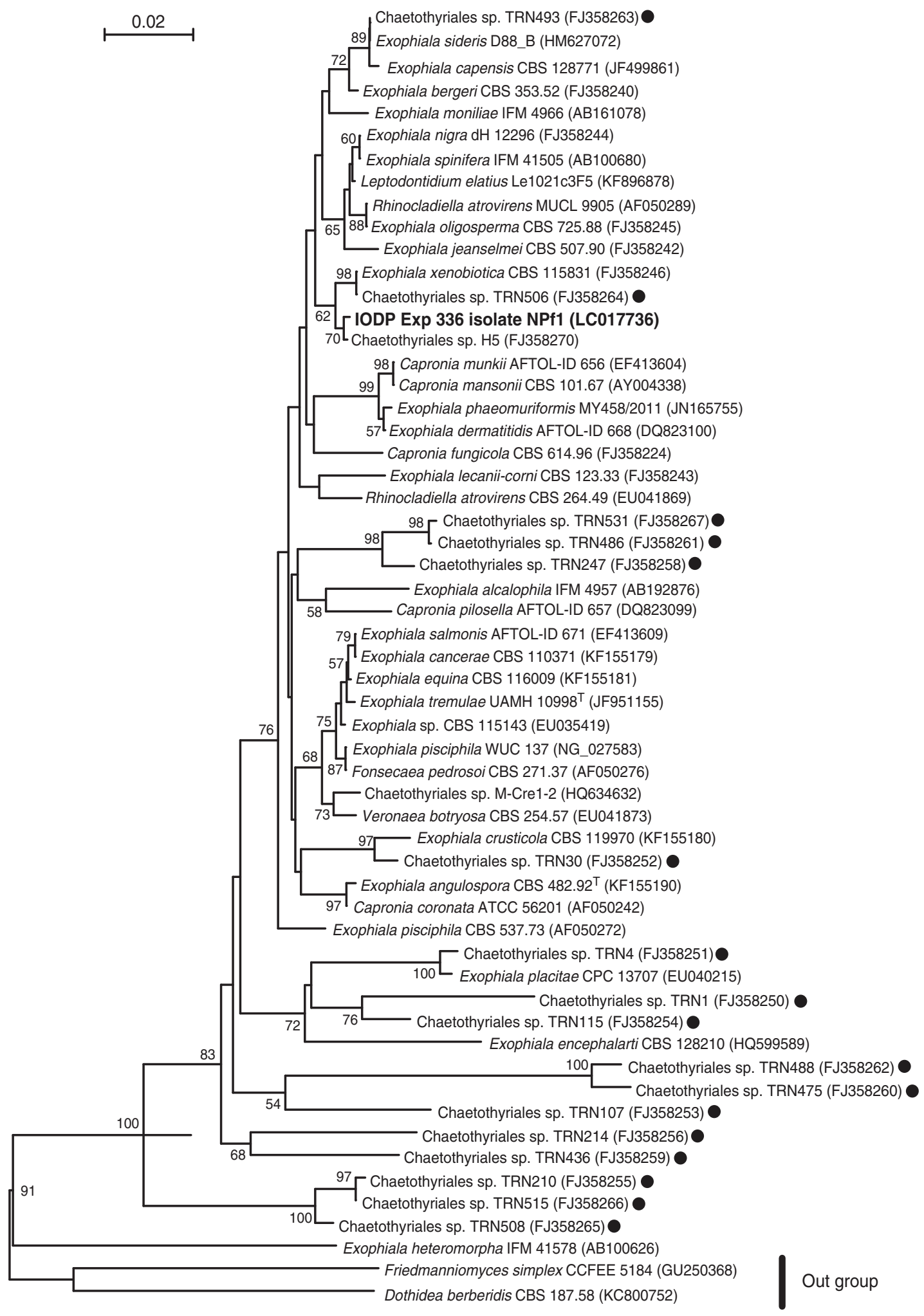


Table T1. Cultivation media used in this study.

\begin{tabular}{|c|c|c|c|}
\hline Target microorganisms & Medium & Headspace gas & Reference \\
\hline Methanogens & MMJ medium & $\mathrm{H}_{2}: \mathrm{CO}_{2}(80: 20,300 \mathrm{kPa})$ & Takai et al., 2002 \\
\hline Anaerobic hydrogen oxidizers & $\begin{array}{l}\text { DSMZ medium } 383 \text { using the basic seawater } \\
\text { medium with resazurin }(1 \mathrm{mg} / \mathrm{L}) \text { instead of } \\
\text { Solution } \mathrm{A}\end{array}$ & $\mathrm{H}_{2}: \mathrm{N}_{2}: \mathrm{CO}_{2}(70: 20: 10,200 \mathrm{kPa})$ & $\begin{array}{l}\text { www.dsmz.de/microorganisms/medium/ } \\
\text { pdf/DSMZ_Medium383.pdf }\end{array}$ \\
\hline Aerobic hydrogen oxidizers & $\begin{array}{l}\text { Basic seawater medium supplemented with } \\
\text { the following per } 1 \mathrm{~L} \text { : } \\
0.5 \mathrm{~g} \mathrm{NaHCO} \\
2.5 \mathrm{mg} \mathrm{NiCl} \cdot 6 \mathrm{H}_{2} \mathrm{O}, \\
2.5 \mathrm{mg} \mathrm{Na} \mathrm{WO}_{4} \cdot 2 \mathrm{H}_{2} \mathrm{O}, \\
0.1 \mathrm{mg} \mathrm{Na} \mathrm{SeO}_{3} \cdot 5 \mathrm{H}_{2} \mathrm{O}, \\
1 \mathrm{~mL} \text { trace element solution } \mathrm{SL}-10 \text { (DSMZ } \\
\text { medium } 320 \text { ), and } \\
1 \mathrm{~mL} \text { vitamin complex solution (DSMZ } \\
\text { medium } 141 \text { ) }\end{array}$ & $\mathrm{H}_{2}: \mathrm{N}_{2}: \mathrm{O}_{2}: \mathrm{CO}_{2}(49: 47: 3: 1,200 \mathrm{kPa})$ & $\begin{array}{l}\text { www.dsmz.de/microorganisms/medium/ } \\
\text { pdf/DSMZ_Medium320.pdf } \\
\text { www.dsmz.de/microorganisms/medium/ } \\
\text { pdf/DSMZ_Medium141.pdf }\end{array}$ \\
\hline Aerobic sulfur oxidizers & $\begin{array}{l}\text { The medium described above for aerobic } \\
\text { hydrogen oxidizers with } 1 \mathrm{mM} \text { sodium } \\
\text { thiosulfate and } \sim 0.1 \mathrm{~g} \text { elemental sulfur per } \\
\text { tube }\end{array}$ & $\mathrm{N}_{2}: \mathrm{O}_{2}(95: 5,100 \mathrm{kPa})$ & \\
\hline
\end{tabular}

Basic seawater medium $=0.06 \mathrm{~g} \mathrm{KH}_{2} \mathrm{PO}_{4}, 0.17 \mathrm{~g} \mathrm{Na}_{2} \mathrm{HPO}_{4}$, and $0.25 \mathrm{~g} \mathrm{NH}_{4} \mathrm{NO}_{3}$ per $\mathrm{L}$ of artificial seawater MARINE ART SF-1. MMJ $=$ marine medium salts in artificial seawater. 
Table T2. Detection of anaerobic microorganisms in the enrichment cultures from the basaltic rock cores.

\begin{tabular}{|c|c|c|c|c|c|c|c|c|}
\hline & \multirow{2}{*}{\multicolumn{2}{|c|}{$\begin{array}{r}\text { Target metabolism: } \\
\text { Energy source: } \\
\text { Temperature: }\end{array}$}} & \multicolumn{3}{|c|}{$\begin{array}{l}\text { Methanogen } \\
\text { Hydrogen }\end{array}$} & \multicolumn{3}{|c|}{$\begin{array}{l}\text { Hydrogen oxidizer (sulfate reducer and nitrate reducer) } \\
\text { Hydrogen }\end{array}$} \\
\hline & & & \multirow{2}{*}{$\begin{array}{l}15^{\circ} \mathrm{C} \\
\mathrm{GC}\end{array}$} & \multirow{2}{*}{$\begin{array}{c}37^{\circ} \mathrm{C} \\
\mathrm{GC}\end{array}$} & \multirow{2}{*}{$\begin{array}{c}55^{\circ} \mathrm{C} \\
\mathrm{GC}\end{array}$} & \multirow{2}{*}{$\begin{array}{l}15^{\circ} \mathrm{C} \\
\mathrm{PCR}\end{array}$} & \multicolumn{2}{|r|}{$37^{\circ} \mathrm{C}$} \\
\hline & Exam & ation by: & & & & & PCR & 16S rRNA gene sequences* \\
\hline Core & Depth (mbsf) & $\begin{array}{l}\text { Section, } \\
\text { piece }\end{array}$ & & & & & & \\
\hline \multicolumn{9}{|c|}{ 336-U1382A- } \\
\hline \multirow[t]{5}{*}{$3 R$} & $113.6-118.3$ & $1 \mathrm{~A}$ & - & - & - & - & - & \\
\hline & & $2 \mathrm{~B}$ & - & - & - & - & - & \\
\hline & & $3 \mathrm{~A}$ & - & - & - & - & + & Bacillus niacini 98\% (Bacilli) \\
\hline & & $4 \mathrm{~A}$ & - & - & - & - & - & \\
\hline & & $4 \mathrm{~B}$ & - & - & - & - & + & Methylobacterium fujisawaense $99 \%$ (AP) \\
\hline $4 \mathrm{R}$ & $123.0-124.8$ & $2 \mathrm{E}$ & - & - & - & - & - & \\
\hline \multirow[t]{2}{*}{$5 \mathrm{R}$} & $132.5-134.6$ & 1B & - & - & - & - & + & Bacillus niacini 98\% (Bacilli) \\
\hline & & $2 \mathrm{E}$ & - & - & - & - & - & \\
\hline \multirow[t]{2}{*}{$6 \mathrm{R}$} & $142.4-143.8$ & $1 \mathrm{~A}$ & - & - & - & - & + & Sphingomonas ursincola $99 \%$ (AP) \\
\hline & & 1C & - & - & - & - & - & \\
\hline $7 \mathrm{R}$ & $153.1-153.9$ & $2 \mathrm{~B}$ & - & - & - & - & - & \\
\hline \multirow[t]{3}{*}{$8 \mathrm{R}$} & $161.3-164.0$ & 1C & - & - & - & - & - & \\
\hline & & 4D & - & - & - & - & - & \\
\hline & & $4 \mathrm{E}$ & - & - & - & - & - & \\
\hline $9 \mathrm{R}$ & $171.5-173.8$ & 1B & - & - & - & - & + & Not identified \\
\hline \multicolumn{9}{|c|}{ 336-U1383C- } \\
\hline \multirow[t]{2}{*}{$2 \mathrm{R}$} & $69.9-72.2$ & $1 \mathrm{C}$ & - & - & - & - & + & Bacillus niabensis 99\% (Bacilli) \\
\hline & & 2D & - & - & - & - & - & \\
\hline $4 \mathrm{R}$ & $86.6-88.1$ & 2D & - & - & - & - & - & \\
\hline $5 \mathrm{R}$ & $96.4-97.2$ & $1 \mathrm{~A}$ & - & - & - & - & + & Bacillus niabensis $99 \%$ (Bacilli) \\
\hline $8 \mathrm{R}$ & $124.7-126.0$ & 1B & - & - & - & - & - & \\
\hline $11 \mathrm{R}$ & $153.8-154.5$ & 1C & - & - & - & - & - & \\
\hline $17 R$ & $202.1-203.1$ & $1 \mathrm{~A}$ & - & - & - & - & - & \\
\hline \multirow[t]{2}{*}{$19 \mathrm{R}$} & $212.1-212.6$ & $1 \mathrm{~A}$ & - & - & - & - & + & Bacillus niacini 99\% (Bacilli) \\
\hline & & $1 \mathrm{C}$ & - & - & - & - & + & Bacillus niabensis $99 \%$ (Bacilli) \\
\hline $20 \mathrm{R}$ & $219.4-220.7$ & $1 \mathrm{~A}$ & - & - & - & - & - & \\
\hline $23 \mathrm{R}$ & $248.1-248.3$ & $1 \mathrm{~A}$ & - & - & - & - & - & \\
\hline $24 \mathrm{R}$ & $256.6-257.1$ & $1 \mathrm{~A}$ & - & - & - & - & - & \\
\hline $29 \mathrm{R}$ & $299.9-300.0$ & $1 \mathrm{~A}$ & - & - & - & - & - & \\
\hline \multirow[t]{3}{*}{$30 \mathrm{R}$} & $304.0-306.3$ & $1 \mathrm{~A}$ & - & - & - & - & - & \\
\hline & & $2 B$ & - & - & - & - & - & \\
\hline & & $3 \mathrm{C}$ & - & - & - & - & - & \\
\hline $31 \mathrm{R}$ & $312.2-314.8$ & 1B & - & - & - & - & - & \\
\hline \multicolumn{9}{|c|}{ 336-U1384A- } \\
\hline $12 x$ & 95.2 & $1 \mathrm{C}$ & - & - & - & - & - & \\
\hline
\end{tabular}

* = closest microorganisms indicated by Blast search. GC = gas chromatography, PCR = polymerase chain reaction. Phylogenetic groups are shown in parentheses. $\mathrm{AP}=$ Alphaproteobacteria. 


\begin{tabular}{|c|c|c|c|c|c|c|c|c|c|c|c|}
\hline & \multirow{3}{*}{\multicolumn{2}{|c|}{$\begin{array}{r}\text { Target metabolism: } \\
\text { Energy source: } \\
\text { Temperature: } \\
\text { Examination by: }\end{array}$}} & \multicolumn{6}{|c|}{$\begin{array}{l}\text { Hydrogen oxidizer } \\
\text { Hydrogen }\end{array}$} & \multicolumn{3}{|c|}{$\begin{array}{c}\text { Sulfur oxidizer } \\
\text { Elemental sulfur and thiosulfate }\end{array}$} \\
\hline & & & \multicolumn{2}{|r|}{$8^{\circ} \mathrm{C}$} & \multicolumn{2}{|r|}{$25^{\circ} \mathrm{C}$} & \multicolumn{2}{|r|}{$37^{\circ} \mathrm{C}$} & \multirow{2}{*}{$\frac{15^{\circ} \mathrm{C}}{\mathrm{PCR}}$} & \multicolumn{2}{|r|}{$37^{\circ} \mathrm{C}$} \\
\hline & & & PCR & 16S rRNA gene sequences & PCR & 16S rRNA gene sequences & PCR & 16S rRNA gene sequences & & PCR & 16S rRNA gene seq. \\
\hline Core & Depth (mbsf) & $\begin{array}{l}\text { Section, } \\
\text { piece }\end{array}$ & & & & & & & & & \\
\hline \multicolumn{12}{|c|}{ 336-U1382A- } \\
\hline \multirow[t]{5}{*}{$3 R$} & $113.6-118.3$ & $1 \mathrm{~A}$ & - & & - & & - & & - & - & \\
\hline & & $2 \mathrm{~B}$ & - & & + & Ralstonia pickettii 99\%-100\% (BP) & - & & - & - & \\
\hline & & $3 \mathrm{~A}$ & - & & - & & + & Paenibacillus darwinianus 97\% (Bacilli) & - & - & \\
\hline & & $4 \mathrm{~A}$ & - & & - & & - & & - & - & \\
\hline & & $4 \mathrm{~B}$ & - & & - & & - & & - & - & \\
\hline $4 \mathrm{R}$ & $123.0-124.8$ & $2 \mathrm{E}$ & - & & - & & - & & - & - & \\
\hline \multirow[t]{2}{*}{$5 \mathrm{R}$} & $132.5-134.6$ & 1B & + & Pseudomonas fluorescens 98\% (GP) & - & & - & & - & - & \\
\hline & & $2 \mathrm{E}$ & - & & - & & - & & - & - & \\
\hline \multirow[t]{2}{*}{$6 \mathrm{R}$} & $142.4-143.8$ & $1 \mathrm{~A}$ & + & $\begin{array}{l}\text { Salinibacterium amurskyense } 100 \% \text { (Act) } \\
\text { Sphingomonas changbaiensis } 96 \% \text { (AP) } \\
\text { Sphingomonas indica } 97 \% \text { (AP) }\end{array}$ & + & Not identified & - & & - & - & \\
\hline & & 1C & + & Ralstonia pickettii 99\%-100\% (BP) & - & & + & Paenibacillus thermoaerophilus 92\% (Bacilli) & - & - & \\
\hline $7 \mathrm{R}$ & $153.1-153.9$ & $2 B$ & + & Not identified & - & & - & & - & + & $\begin{array}{l}\text { Moraxella osloensis } \\
98 \%(\mathrm{GP})\end{array}$ \\
\hline \multirow{3}{*}{$8 \mathrm{R}$} & $161.3-164.0$ & 1C & - & & + & Pseudomonas tolaasii 97\% (GP) & - & & - & - & \\
\hline & & $4 \mathrm{D}$ & - & & - & & - & & - & - & \\
\hline & & $4 \mathrm{E}$ & - & & - & & - & & - & - & \\
\hline $9 \mathrm{R}$ & $171.5-173.8$ & $1 \mathrm{~B}$ & + & Pseudomonas fluorescens 98\% (GP) & + & Ralstonia pickettii 99\%-100\% (BP) & - & & - & - & \\
\hline \multicolumn{12}{|c|}{ 336-U1383C- } \\
\hline \multirow[t]{2}{*}{$2 \mathrm{R}$} & $69.9-72.2$ & 1C & - & & - & & + & Paenibacillus thermoaerophilus 92\% (Bacilli) & - & - & \\
\hline & & 2D & + & Ralstonia pickettii 99\%-100\% (BP) & - & & + & Acidovorax ebreus 99\% (BP) & - & + & Not identified \\
\hline $4 \mathrm{R}$ & $86.6-88.1$ & 2D & + & Pseudomonas fluorescens $98 \%$ (GP) & - & & - & & - & - & \\
\hline $5 \mathrm{R}$ & $96.4-97.2$ & $1 \mathrm{~A}$ & - & & - & & + & Acidovorax ebreus 99\% (BP) & - & - & \\
\hline $8 \mathrm{R}$ & $124.7-126.0$ & 1B & + & Ralstonia pickettii 99\%-100\% (BP) & - & & + & Not identified & - & - & \\
\hline $11 \mathrm{R}$ & $153.8-154.5$ & 1C & - & & - & & + & Not identified & - & - & \\
\hline $17 \mathrm{R}$ & $202.1-203.1$ & $1 \mathrm{~A}$ & + & Sphingomonas paucimobilis $99 \%$ (AP) & - & & + & Phenylobacterium koreense 94\% (AP) & - & - & \\
\hline \multirow[t]{2}{*}{$19 \mathrm{R}$} & $212.1-212.6$ & $1 \mathrm{~A}$ & - & & - & & + & Acidovorax ebreus $99 \%$ (BP) & - & - & \\
\hline & & 1C & - & & - & & + & Paenibacillus darwinianus $97 \%$ (Bacilli) & - & - & \\
\hline $20 \mathrm{R}$ & $219.4-220.7$ & $1 \mathrm{~A}$ & - & & - & & - & & - & - & \\
\hline $23 \mathrm{R}$ & $248.1-248.3$ & $1 \mathrm{~A}$ & - & & - & & - & & - & - & \\
\hline $24 \mathrm{R}$ & $256.6-257.1$ & $1 \mathrm{~A}$ & - & & & Exophiala sp. (Fungi) & + & Paenibacillus darwinianus $97 \%$ (Bacilli) & - & - & \\
\hline $29 \mathrm{R}$ & $299.9-300.0$ & $1 \mathrm{~A}$ & + & Ralstonia pickettii 99\%-100\% (BP) & + & Not identified & + & Paenibacillus thermoaerophilus 92\% (Bacilli) & - & - & \\
\hline \multirow[t]{3}{*}{$30 \mathrm{R}$} & $304.0-306.3$ & $1 \mathrm{~A}$ & - & & + & Pseudomonas fluorescens 99\% (GP) & - & & - & - & \\
\hline & & $2 \mathrm{~B}$ & - & & + & Ralstonia pickettii 99\%-100\% (BP) & - & & - & - & \\
\hline & & $3 \mathrm{C}$ & - & & - & & + & Acidovorax ebreus 99\% (BP) & - & - & \\
\hline $31 \mathrm{R}$ & $312.2-314.8$ & 1B & - & & - & & - & & - & - & \\
\hline \multicolumn{12}{|c|}{ 336-U1384A- } \\
\hline $12 \mathrm{X}$ & 95.2 & 1C & - & & - & & - & & - & - & \\
\hline
\end{tabular}

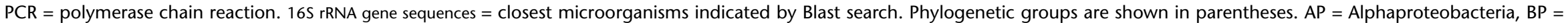
Betaproteobacteria, GP = Gammaproteobacteria, Act = Actinobacteria. Not identified $=$ direct sequencing did not succeed 
Table T4. Detection of microorganisms in the sediment cores: real-time PCR for methanogens and the cultivation of sulfur oxidizers.

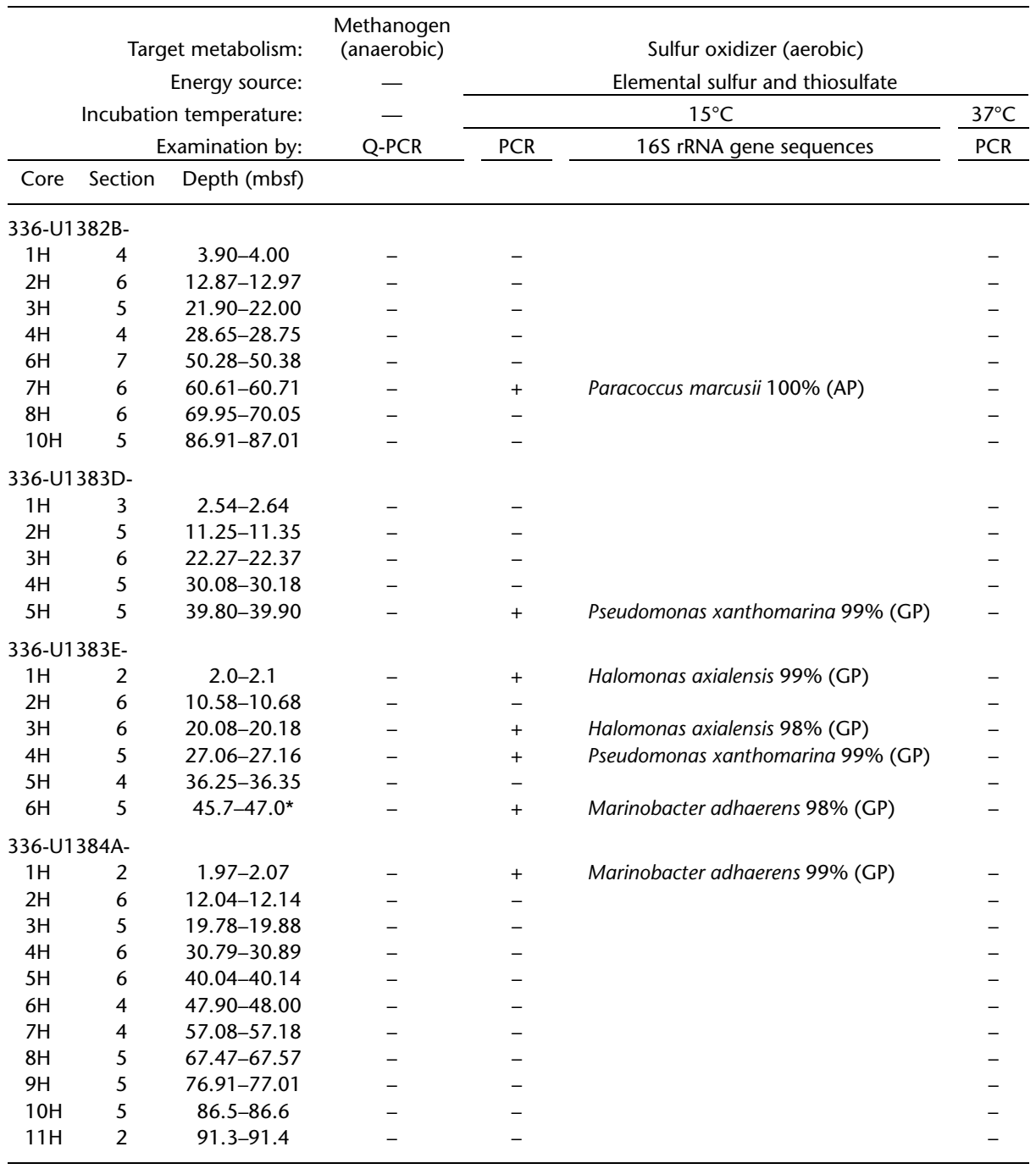

* = depth at which the master core for microbiology was collected. Q-PCR = real-time PCR experiment. PCR $=$ polymerase chain reaction. $16 \mathrm{~S}$ rRNA gene sequences = closest microorganisms indicated by Blast search. Phylogenetic groups are shown in parentheses. AP $=$ Alphaproteobacteria, GP = Gammaproteobacteria. 